\title{
ПЕРСПЕКТИВЫ ПРИМЕНЕНИЯ МЕТОДА КЕЙС-СТАДИ ПРИ ИЗУЧЕНИИ АВТОРСКИХ НЕОЛОГИЗМОВ В ПРОИЗВЕДЕНИЯХ КУРТА ВОННЕГУТА (НА МАТЕРИАЛЕ НЕОЛОГИЗМОВ РОМАНА “КОЛЫБЕЛЬ ДЛЯ КОШКИ")
}

В статье рассматривается роль неологизмов в процессах самоорганизации текста. Также, обсуждается метод кейсстади и его применимость в исследованиях данного типа.

Ключевые слова: кейс-стади, текст, неологизмы, смыслопорождение, механизмы смыслообразования

The article deals with the role of neologisms in the processes of self-organisation in the text. In addition, the article deals with the method of the case study and its application to researches of this type.

Key Words: case study, text, neologisms, self-organisation, ways of text self-organisation.

Текст в современной лингвистике может рассматриваться с применением новых, нетрадиционных методик, раннее не использовавшихся для данных целей, поскольку в современной интерпретации лингвистики стало возможным некое "размытие границ" и привлечение методов других наук. Данная стратегия может способствовать получению новых результатов, которые не представлялось возможным получить, используя старые, сугубо языковые методы исследования.

Данная работа строится на исследовании неологизмов в романах Курта Воннегута. Творчество американского писателясатирика привлекает не только читателей, но и исследователей. Его романы отличаются новизной содержания и своеобразной формой - при каждом новом прочтении удается выявить все новые слои смысла. Особый интерес для исследователей представляют неологизмы в произведениях писателя. Авторские неологизмы - “слово, созданное писателем, поэтом, публицистом 
для обозначения новых или выдуманных предметов, или понятий” [Москалева 2003:22].

В романе "Колыбель для кошки" неологизмы используются для обозначения особой идеологии, или религии и всех вещей из которых она состоит, или, так или иначе с ней связанных: wrangwrang, sin-wat, wampeter, karass, kankan, calypso, granfaloon, bokomaru, sinookas и другие. Исследование также рассматривает саму систему текста и процесс смыслообразования, построенный на неологизмах. В результате работы предполагается ответить на ряд вопросов. С какой целью и для чего автор вводит неологизмы? Образуют ли они систему и как развивается направление смысла? Поскольку задача очень сложная и в процессе работы исследование может поменять направление, то за основу методики был взят метод Л.В. Бронник и носящий название кейс-стади. Метод кейс-стади представляет собой множество модификаций. Стратегии кейс-методологии могут носить объяснительный или описательный характер. Среди плюсов Бронник отмечает 1) проблемный характер объекта исследования, 2) кейс-стади обладает статусом полноценного научного метода, 3) целостность метода, 4) отсутствие жесткой схемы и возможность изменения метода исследования, 5) метод применим при исследовании сложных самоорганизующихся систем, 6) позволяет рассмотреть объект в его движении, 7) в качестве заключительного этапа исследователь делится своими результатами. Данный метод является отправной точкой исследования и предполагает процесс своей модификации, при условии обнаружения более точного инструмента исследования [Бронник 2011: 295].

Так, например, для изучения самоорганизации концепта karass был применен метод кейс-стади. На первом этапе был выделен синонимический ряд. На следующем этапе были определены параметры состояния. В результате анализа были получены данные, говорящие о том, что концепт karass обозначает "группу людей, объединившихся друг с другом для достижения определенной цели по религиозным мотивам" [Закиева 2020:109].

Для проверки полученных результатов в романе Курта Воннегута методом сплошной выборки был выделен ряд 
отрывков, в которых упоминается концепт karass. В результате данный концепт обладает следующими чертами:

1. Человеческое общество организовано по карассам (группам).

$2 . \quad$ Есть специальный инструмент (кан-кан), который распределяет людей по карассам.

3. Для карасса не существует каких-либо границ. Самые разные люди могут в него попасть.

4. В карассы могут входить люди, которые вам не нравятся ли которым не нравитесь вы.

5. Ось любого карасса называется - вампитер. Вампитером может быть все, что угодно.

6. Разновидности карасса - дюпрасс (карасс, состоящий из двух человек).

7. Ложный карасс называется гранфаллоном.

Определение концепта, полученное при помощи метода кейс-стади отличается от данного автором. Определение данное Воннегутом гораздо глубже и сложнее. Данные результаты позволяют сделать вывод о том, что процесс смыслообразования в романе Курта Воннегута обладает сложной структурой и требует более тщательного изучения и применения новых комплексных подходов.

Лингвосинергетика предлагает большое количество методик изучения текста, а также возможность бленда методов для получения более точных результатов исследования. функционирования английских и русских неологизмов / Е.В. Москалева дисс.: канд. филол. наук. - М., 2003. - С 4-26.

2. Бронник Л.В. Самоорганизация концепта в дискурсе // Филологические науки. Теория и практика общественного развития. 2011 №1 [Электронный ресурс]. URL: https://cyberleninka.ru/article/n/samoorganizatsiya-kontsepta-vdiskurse-keys-stadi (дата обращения 01.05.2021).

3. Закиева И.Т. Авторские неологизмы в художественном дискурсе Курта Воннегута // Казанская наука, 2020 №12. c. 108-110.

(С) Закиева И.Т. 2021 г. 